тих же умов зменшуються інтенсивність: поглинання кисню на $28 \%$, виділення вуглекислого газу на $77 \%$, втрати сухих речовин на $77 \%$ і виділення теплової енергії на $77 \%$. Встановлені закономірності перебігу фізіологічних прочесів у зерні кукурудзи з різною початковою вологістю при зберіганні в герметичних умовах за різних температур дозволяють прогнозувати характеристики газообмінних процесів у зерновій масі, природні втрати сухих речовин та виділення теплоти при зберіганні зерна.

Ключові слова: зерно кукурудзи, полімерні зернові рукави, герметичні умови зберігання, поглинання кисню, виділення вуглекислого газу, виділення теплоти, втрати сухих речовин.

\title{
ЛІТЕРАТУРА
}

1. Трисвятский, Л.А. Хранение зерна: изд. 4-е перераб. и доп.[Текст]/ Л.А. Трисвятский. - М.: Колос, 1975. - 400 с.

2. Бабков А.В., Желобкова М.В. Дослідження агротехнологічних характеристик зерна окремих гібридів кукурудзи // Наук. пр. / Одес. наи. акад. харч. технологій. Одеса, 2018. T. 82, вип. 2. С. $106-115$.

3. ДСТУ 4525:2006 Національний стандарт Украйни. Кукурудза. Технічні умови. URL: http://zernodisp.com.ua/userfiles/files/normativnye_dokumenty/dstu-4525-2006-kukuruza.pdf (дата звернення 12.11.2018).

4. Сигнализаторы-анализаторы газов, горючих газов и паров «ДОЗОP-C». URL: www.orion.com.ua (дата звернення 12.11.2018).

5. Станкевич, Г.Н. Современный подход к изучению интенсивности дыхания зерна [Текст] / Г.Н. Станкевич, А.В. Бабков, М.Ж. Кизатова // Вестн. Алмат. технолог. ун-та. 2014. Bып. 2(103). C. 45-51.

Надійшла 11.12.2018 р. Рецензія 15.12.2018.

До друку 19.12.2018.

Адреса для переписки:

вул. Канатна, 112, м. Одеса, 65039

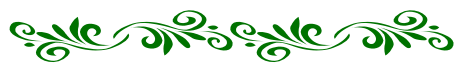

\section{STUDY OF MOISTURE ABSORPTION OF SWEET CORN GRAIN OF DIFFERENT FRACTIONS}

\begin{abstract}
Annotation
In Ukraine, as the raw material for the production of cereals, flour, flakes, the following main crops are used: wheat, barley, buckwheat, oats, corn, rice, millet, peas. The volume of world grain production has grown significantly in recent years. In Ukraine, corn is the main fodder crop, and only a small amount is used as a food. Corn has the leading place among the major grain crops in world agricultural production. Corn grain production is concentrated in warm regions. In some regions, corn is the basis of the traditional nutrition of the population, but basically it forms part of the feed in the feeding of farm animals.

Today about 3500 food and technological products are produced from corn. Corn can largely satisfy the needs of livestock, its share is almost 30\% of concentrated feed. With the advent of new directions in the development of biotechnology in the world, the significance of this culture will increase even more. The programs of biofuel production are gaining momentum, in connection with which a significant expansion of the sown area under the corn is foreseen.

In this article features of water-heat treatment of corn grain during preparation for processing are provided. Features of the use of hot and cold grain conditioning in the cereal industry are considered. In the course of this study, it was determined that the optimum water temperature for humidifying corn sugar is $60{ }^{\circ} \mathrm{C}$. Using a certain water temperature during humidification will enable to perform more efficiently the directed change of technological properties of grain, to ensure the high efficiency of its further processing. The results of research of the water absorption capacity of sugar corn grain are presented. As can be seen from the research carried out to improve the efficiency of the STI and optimize the processing technology, the grain lots are fractionated into more homogeneous flows of physical properties and treated separately.
\end{abstract}

Key words: grain processing, corn, water absorption, hydrothermal grain processing.

\section{Introduction}

Corn is a highly productive plant of tropical origin. Its homeland is Middle and South America, which explains the needs of the plant in warmth for its growth and development $[4,5,7]$. It is the most productive grain crop that is widely used as:

- raw materials in the food, pharmaceutical, chemical and other industries;

- high-energy feed suitable for feeding all types of animals and poultry;
- raw materials for the production of biofuels of the first and second generations;

- raw materials for biogas production.

The agrotechnological significance of this crop is also great, as it clears the soil from weeds and is a good precursor in the crop rotation. Due to the absorption of carbon dioxide and the release of oxygen, corn holds one of the first places among all cultivated plants and is even more effective than the forest of a similar area [6, 8]. Valuable properties of corn cause its stable high de 


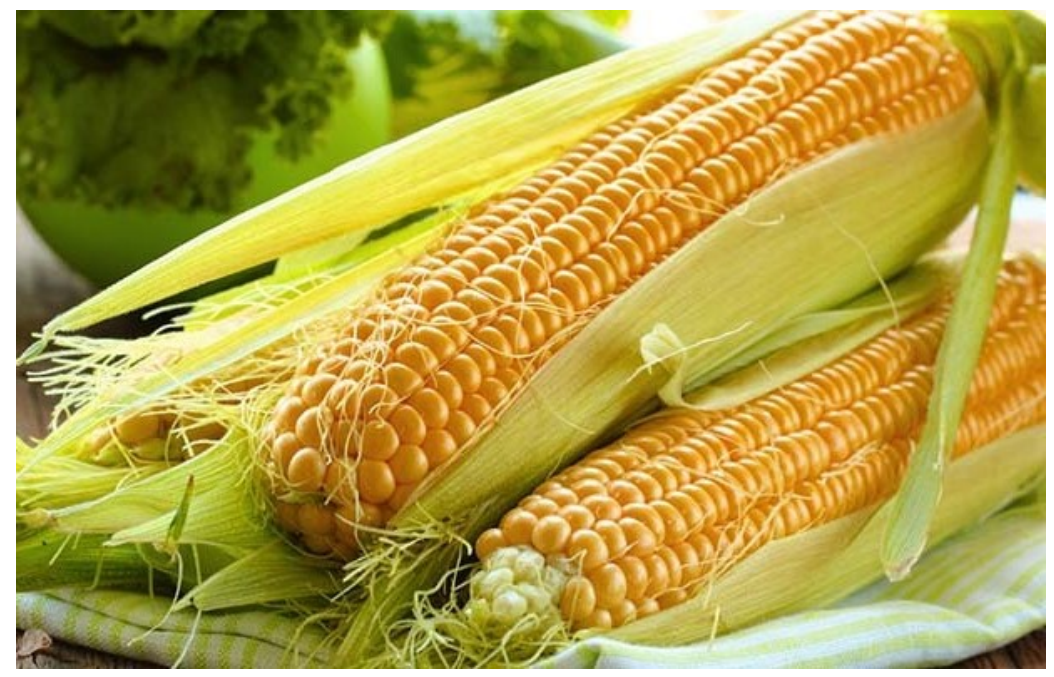

steadily declining. It should be noted that less than $2 \%$ of produced grain is used for processing into cereals in Ukraine. Despite the fact that the growth of the raw material base is a prerequisite for increasing the volume of processing, the main constraining factor in this segment is the low demand for products due to the low quality of finished products and the lack of a culture of consumption of corn cereals in most Ukrainian residents.

mand on the world market. In terms of the gross harvest of grain, yields and areas, corn, among other grains, is fifth in the world [1].

Thus, given the large area under corn for grain in Ukraine, which occupy about $15 \%$ of the area of arable land, and high yields in recent years (on average, from 57 to $64 \mathrm{c} / \mathrm{ha}$ ), it is obvious that this agricultural crop forms, in addition to grain, large quantities of byproducts that can be used in the bioenergy sector. It can be noted that Ukraine has reserves for increasing yields due to wider use of the achievements of agrarian science. In order to ensure stable corn prices, it is necessary to increase its internal consumption, including through processing for the receipt of goods with high added value [10-12].

\section{research \\ Problem formulation and analysis of recent}

In accordance with the existing technological regulations, three types of cereal product are produced from corn: dry ground corn, large grains for flakes and small grains for sticks [3-6]. In turn, depending on the size, the dry ground corn is divided into five numbers. Corn contains a large amount of carbohydrates (over $70 \%$ ), a small amount of proteins (about 8.3\%), and with the correct administration of the technological process of production - a minimum of fat (up to $1.2 \%$ ). In addition, this product has a fairly rich vitamin content and contains vitamins of groups A, B, E, H. RR and also B-carotene. Macronutrients in corn cereal are represented mainly by potassium, phosphorus and sulfur, and among the microelements are iron, zinc and manganese. The total nutritional value of corn cereal is about $328 \mathrm{kcal} / 100 \mathrm{~g}$ [3, 5, 9].

The traditional technology of corn production does not have a complex grain cleaning scheme, which includes two stages of cleaning on air-screen separators and treatment on a stone separating machine. The direct processing scheme for purified grains includes the such stages as hydrothermal treatment, grinding in a germinator with a separation of the corcule, peeling, and grinding, and sorting on a shaking machine and pneumatic sorting tables [6].

In Ukraine, despite the increase in corn production, the number of enterprises producing corn grits is ing the technological process of production of cereals and cereal products in the processing of corn grain.

The subject of the study is the sugar corn grain of crops in 2016, 2017 and 2018 grown in the Odesa region in farming. The purpose of this study is to determine the water absorption capacity of corn grain of large and medium fractions, to determine the parameters of optimal water temperature at the stage of water-heat treatment of grain during its preparation for processing.

Hot and cold grain conditioning systems are the most commonly used methods in cereal production to ensure the effective implementation of the water-heat treatment stage. Hot air conditioning is steaming of grain at excess pressure, while the moisture penetrates more intensively into the grain, providing its strength and ductility. The factors that determine the process of hot air conditioning are the saturated vapor pressure and steaming time. In the process of steam grain processing on the surface of the grain environment is created with a high relative humidity and temperature, which forms a temperature and moisture gradient, which helps to change the properties of the main components of the inner part of the grains. After steaming, the grain is dried and cooled. The method of hot air conditioning is mainly used in the processing of grain crops, which are covered with surface films. Cold air conditioning is a simpler method, which is to moisturize the grain with water and then soak it. The main factors that determine the process of cold air conditioning are the degree of humidification and time of soaking. After humidification of the grain to ensure a uniform distribution of moisture in the grains it is hydrated in special tankers and then sent for processing $[2,8]$.

The nature of grain and water interaction is determined by the influence of the sorption properties of the grain, parameters of the moisture carrier and the environment. In practice, the humidification of the grain is carried out with water, with full immersion in water or steam with different parameters. The surface of the grain as a biological object has hollow tubular cells and is adapted for rapid absorption of moisture, which is necessary at the initial stage of development of the future plant. In this case, the amount of initially absorbed water is numerically equal to the moisture content of the outer shells. In this case, moisture curves develop gradually [4$6]$. 
Steaming

humidification is carried out either with a moisture saturated with vapor, or overheated steam. It is believed that during steaming there is a more

uniform humidification of the grain surface, which creates favorable conditions for hydrothermal treatment in general. Simultaneously with humidification there is a warming of the grain, which increases the rate of moisture diffusion from the periphery to the center. The thermal effect in determining the temperature parameters can lead to profound changes in the grain, which will affect the technological properties.

In the cereal technology, optimum humidity varies greatly also depending on the type of processed grain and the type of technology. In the processing of corn into cereal for flakes and sticks, humidity is raised to $19.0-22.0 \%$, which is due to the need for plasticizing of the corcule and its subsequent separation without shattering $[4,5]$.

In the process of interaction of grain with water, an important factor is the time. First of all, it manifests itself in the duration of grain humidification. Studies have shown that as the temperature of the absorbed water increases, the moisture absorption capacity of the grain increases with evaporation [6].

In order to determine the water absorption capacity, the grains of sugar corn crops from 2016-2018 were soaked at different temperature regimes: 20, 40, $60^{\circ} \mathrm{C}$, after which the relative humidity of the grain was determined in accordance with GOST 13586.5-93.

The initial moisture content of the investigated corn grain of large and medium fractions was $12.9 \%$ and $12.8 \%$ respectively.

The results of studies on the water absorption capacity of sugar corn are shown in Fig. 1-2.

\section{Conclusions}

From the above results it can be seen that the absorption of moisture by the grain was gradual. As the temperature increased, the absorption capacity increased.

\section{oisture content of corn grain average fraction $\left(T_{B}=20^{\circ} \mathrm{C} ; T_{B}=40^{\circ} \mathrm{C} ; T_{B}=60^{\circ} \mathrm{C}\right)$}

Although the grain of different years was researched, the tendency of moisture absorption by the grain of large and medium fractions was maintained.

The obtained results make it possible to trace the dependence: when the temperature of water increases from $20^{\circ} \mathrm{C}$ to $60^{\circ} \mathrm{C}$ for 120 minutes, the moisture content of sugar corn is increased by $13.89 \%$ for the corn of the large fraction and by $14.13 \%$ for the corn of the average fraction, respectively.

The research was limited to a temperature of $60^{\circ}$ $\mathrm{C}$, as the temperature increase would dissolve in the water a part of the chemical elements that are part of the grain structure, which correspondingly reduces its nutritional value, while the presence of organic elements in water will necessitate its additional purification.

In the course of this study, it was determined that the optimum water temperature for humidifying corn sugar is $60{ }^{\circ} \mathrm{C}$. Using a certain water temperature during humidification will enable to perform more efficiently the directed change of technological properties of grain, to ensure the high efficiency of its further processing.

During the humidification, the absorption of moisture by grain of different corn grain fractions passes in different ways. This is due to the relatively high content of the films and the aleuronic layer in the medium 
corn grain fractions, which most actively absorb moisture. Consequently, the features of morphological and anatomical structure and physical and chemical properties in the specific surface cause differences in the kinetics of water absorption of corn grain of different fractions by size. For a uniform distribution of the water introduced, a certain period of time is required, the duration of which is influenced by the grain size. As can be seen from the studies conducted, it is obvious that for smaller grain sizes this time period will be shorter than for large grain. Therefore, in order to increase the efficiency of the STI and optimize the processing technology, grain lots are fractionated into streams more homogeneous by physical properties and treated separately.

\section{REFERENSES}

1. Derzhkomstat Ukrayini : [Veb-sayt]. URL: http://www.ukrstat.gov.ua

2. Pravila orhanizatsiyi i vedennya tekhnolohichnoho protsesu na krup'yanikh zavodakh. Kiyiv, 1998.164 s.

3. Shutenko YI., Sots S.M. Tekhnolohiya krup'yanoho virobnitstva: navchal 'niy posibnik. Kiyiv: Osvita Ukrayini, 2010.272 s.

4. Merko I.T., Morhun V.A. Naukovi osnovi i tekhnolohiya pererobki zerna: pidruchnik. Odesa: Druk, 2001.348 s.

5. Chebotarev O.N., Shazzo A.yu., Martynenko ya.F. Tekhnolohiya muki, krupy i kombikormov: učebnik. Moskva: IKTS «Mart», 2004. $688 \mathrm{~s}$

6. Butkovskiy V.A., Mel'nikov A.M. Tekhnolohiya mukomol noho, krupyanoho i kombikormovoho proizvodstva: učebnik. Moskva: Ahropromizdat, 1989. 463 s.

7. Ajzikovič L.E., Senatorskij B.V., Sokolov N.P. Novoev tehnologii mukomol'nogo proizvodstva: učebnik. Moskva: Vysšâ̂ škola, 1966. $126 \mathrm{~s}$.

8. Kazakov E.D. Vlaga v zerne: učebnik. Moskva: Kolos, 1969. 51 s.

9. Špaar Diter, Kukuruza: vyraŝivanie, uborka, hranenie i ispol'zovanie: učebnik. Kiev: ID «Zerno», $2012.462 \mathrm{~s}$.

10. Cikov V.S. Kukuruza: tehnologiâ, gibridy, semena: učebnik. Dnepropetrovsk: Izdatel'stvo Zorâ, $2003.296 \mathrm{~s}$.

11. Drahnev S.V., Zheleznaya T.A., Heletukha H.H. Vozmozhnosti zahotovki pobochnoy produktsii kukuruzy na zerno dlya enerheticheskoho ispol zovaniya v Ukraine. Kiev, 2016. 110 s. (Analiticheskaya zapiska BAU \#16., «Bioenerheticheskaya assotsiatsiya Ukrainy»).

С.М. СОЦ, канд. техн. наук, доцент

О.В. БУНЯК, аспірант

Одеська начіональна академія харчових технологій, м. Одеса

\section{ДОСЛІДЖЕННЯ ПОГЛИНАННЯ ВОЛОГИ ЗЕРНОМ ЦУКРОВӦ̈ КУКУРУДЗИ РІЗНИХ ФРАКЦІЙ}

\section{Аннотація}

В Украӥні як сировину для виробництва крупи, муки, пластівиів використовують такі основні культури: пшеницю, ячмінь, гречку, овес, кукурудзу, рис, просо, горох. Об'єм світового виробництва зерна за останні роки значно виріс. В Україні кукурудза є основною кормовою культурою, і лише в невеликій кількості використовується як продовольча. Кукурудза займає провідне місие серед основних зернових культур в світовому сільськогосподарському виробництві. Виробництво кукурудзи на зерно сконцентровано в теплих регіонах. У деяких регіонах кукурудза є основою традиційного харчування населення, але в основному вона становить частину кормів у годівлі сільськогосподарських тварин.

Сьогодні з кукурудзи виготовляють близько 3500 харчових і технологічних продуктів. Кукурудза здатна значною мірою задовольняти потреби тваринництва, його частка становить майже 30 \% у складі концентрованих кормів. 3 появою нових напрямків у розвитку біотехнологій у світі значення иієї культури зросте ще більше. Набирають обороти програми по виготовленню біопалива, у зв'язку із чим прогнозується значне розширення посівних площ під кукурудзою.

У даній статті наведено особливості воднотеплової обробки зерна иукрової кукурудзи при його підготовиі до переробки. Розглянуто особливості використання гарячого та холодного кондиціювання зерна у круп'яній промисловості. В ході даного дослідження було визначено, щзо оптимальною температурою води для зволоження зерна иукрової кукурудзи є $60^{\circ} \mathrm{C}$. Використання визначеної температури води при зволоженні дасть можливість більш ефективно проводити направлену зміну технологічних властивостей зерна, для забезпечення високої ефективності його подальшої обробки. Представлені результати досліджень водопоглинальної здатності зерна иукрової кукурудзи. Як видно із проведених досліджень для підвищення ефективності ГТО і оптимізаиї технології переробки, партії зерна фракціонують на більи однорідні за фізичними властивостями потоки та обробляють окремо.

Ключові слова: переробка зерна, кукурудза, водопоглинанна, гідротермічна обробка зерна.

\section{ЛITЕРАТУР}

1. Держкомстат Украӥни : [Веб-сайт]. URL: http://www.ukrstat.gov.ua

2. Правила організачї̈ і ведення технологічного прочесу на круп'яних заводах. Київ, 1998. 164 c.

3. Шутенко С.І., Соч С.М. Технологія круп'яного виробництва: навчальний посібник. Київ: Освіта Украӥни, 2010. $272 \mathrm{c}$.

4. Мерко I.T., Моргун В.А. Наукові основи і технологія переробки зерна: підручник. Одеса: Друк, 2001. 348 с.

5. Чеботарев О.Н., Шаззо А.Ю., Мартыненко Я.Ф. Технология муки, крупы и комбикормов: учебник. Москва: ИКЦ «Mapm», 2004. 688 c. 
6. Бутковский В.А., Мельников А.М. Технология мукомольного, крупяного и комбикормового производства: учебник. Москва: Агропромиздат, 1989. 463 c.

7. Айзикович Л.Е., Сенаторский Б.В., Соколов Н.П. Новое в технологии мукомольного производства: учебник. Москва: Высшая школа, 1966. 126 с.

8. Казаков Е.Д. Влага в зерне: учебник. Москва: Колос, 1969. 51 .

9. Шпаар Дитер, Кукуруза: выращивание, уборка, хранение и использование: учебник. Киев: ИД «Зерно», 2012. $462 c$.

10. Задорожний І.М., Гаврилишин В.В. Товарознавство продовольчих товарів. Зерноборошняні товари: підручник для студентів вищих навчальних закладів. Львів: Компакт ЛВ, 2004. 304 с.

11. Циков В.С. Кукуруза: технология, гибриды, семена: учебник. Днепропетровск: Издательство Зоря, 2003.296 с.

12. Драгнев С.В., Железная Т.А., Гелетуха Г.Г. Возможности заготовки побочной продукиии кукурузы на зерно для энергетического использования в Украине. Киев, 2016. 110 с. (Аналитическая записка БАУ №16., "Биоэнергетическая ассоииация Украиныл»).

Надійила 02.02.2019. Рецензія 10.02.2019

До друку 25.02.2019.

Адреса для переписки:

65039, Odessa, str. Kanatnaya 112,

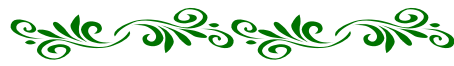

(097) 997-44-83, bunyak.e.v@gmail.com

D. ZHYGYNOV ${ }^{1}$, Dr. Tech. Sciences, Associate Professor, V. KOVALOVA ${ }^{1}$, Post-graduate Student, A. DRAGOMYR ${ }^{1}$, H. ZHYHUNOVA ${ }^{2}$, Master Student, K. ZHANABAYEVA ${ }^{3}$, Senior teacher

${ }^{1}$ Odessa National Academy of Food Technologies, Odessa, Ukraine

${ }^{2}$ The Higher Institute of Agriculture, Lille, France

${ }^{3}$ Kostanay State University named Akhmet Baytursynov, Kostanay, Kazakhstan

\title{
ANALYSIS OF THE QUALITY OF FLOUR FROM DIFFERENT SYSTEMS OF THE TECHNOLOGICAL PROCESS OF A FLOUR MILL
}

\begin{abstract}
Research in the article is aimed to determining the quality of flour from different systems of the technological process of a wheat milling. Samples of flour were obtained at the mill "Rivne Boroshno". Private enterprise "Rivne Boroshno" is one of the largest producers of wheat flour in the western region with a capacity of 180 tons /day. Flour obtained from various systems of milling process, has a very large variety of quality indicators. Whiteness, Gluten Deformation Index, Gluten Content, Protein Content, Ash Content, Water Absorbing Capacity, FN, SD, the rheological properties of dough on the Mixolab device, as well as the quality of baked bread have been evaluated.

During the study, the variability of flour quality indicators on various systems was found. Whiteness varied - from 1 to 71 units, Gluten Deformation Index - from 40 to 100 units, Gluten Content-from 2 to $36 \%$, Protein Content-from 9,8 to 18,2 \%, the FN - from 275 to $374 \mathrm{~s}, \mathrm{SD}$ - from 15 to 30,3 UCD, Ash Content - from 0,31 to 2,23\%, Water Absorbing Capacity - from 53,5 to $69,7 \%$.

In the process of grinding grain and intermediate products, more than twenty flour streams of different quality are produced at the flour mill. From these streams it is required to receive only one or several grades of flour. Naturally, if only one variety is produced, then all flows from different systems are sent to it. The weighted average quality indicators of flour should comply with the requirements of the standard for this grade in terms of Ash Content, Gluten Content, etc.

The maximum Ash Content is observed in the streams from the last reduction systems, as well as from break systems in the milling process, where products with a large number of brans are milled. At the same time, the flour from the central parts of the endosperm is slightly less gluten, but more starch than in the flour from the peripheral parts of the endosperm, which are grinding on subsequent reduction systems.

For the research, samples of flour were taken from each system of the technological process. For convenience, we have arranged them for quality using the indicator of whiteness. One of the main indicators of the quality of flour, which determines its grade, is whiteness. In the studied samples, the values of the whiteness index range from 71 to 1 unit.
\end{abstract}

Key words: flour quality, wheat flour, quality indicators, gluten, protein, Falling Number, Starch Damage

\section{Introduction}

Bread products vary widely around the world, as do their production techniques. Basic ingredients are cereal flour, water, yeast or another leavening agent, and salt $[1,2]$. Wheat is one of the cereals used extensively in many parts of the world for the preparation of bread and many bakery products $[3,4]$. Flour performance depends on its composition, which in turn depends on wheat characteristics and milling. Milling separates the bran and germ fractions from the endosperm, which is used to make flour, and reduces endosperm particles to the correct size [5].

Flours differ in their extraction rate, which is defined as the proportion of flour by weight, derived by 